\title{
FIRST RECORD OF BOTRYOSPHAERIA RIBIS ASSOCIATED WITH LEAF SPOTS ON MAGNOLIA AFF. CANDOLLEI IN BRAZIL
}

\author{
Davi Mesquita de Macedo; Robert Weingart Barreto*
}

Departamento de Fitopatologia, Universidade Federal de Viçosa, Viçosa, MG, Brasil

Submitted: October 05, 2007; Returned to authors for corrections: February 17, 2008; Approved: April 25, 2008.

\section{SHORT COMMUNICATION}

\begin{abstract}
A leaf spot disease was observed attacking some Magnolia aff. candollei plants grown in a private garden in the city of Rio de Janeiro, RJ, Brazil. Such leaf spots coalesced and led to extensive blight of foliage. A fungus was clearly associated to the disease symptoms and was identified as Botryosphaeria ribis. Its anamorph, Fusicoccum ribis, was also present, although less abundant than the teleomorph. This is first report of this fungus on this host in Brazil and the first record of any fungal disease on a member of the genus Magnolia in Brazil.
\end{abstract}

Key-words: Magnoliaceae, ornamental plant, plant disease, plant pathology, taxonomy.

Several members of the Magnoliaceae became popular worldwide as garden shrubs and trees because of their large flowers having a very pleasant scent. In Brazil some species of Magnolia are relatively commonly grown as ornamentals, particularly Magnolia ovata (A. St.-Hil.) Spreng, $M$. grandiflora L., M. liliflora (L.) Baill.and M. champaca (L.) Baill. ex Pierre (14).

A small group of shrubs recognized as belonging to the Magnoliaceae were found to be attacked by a foliar disease in a private garden in the city of Rio de Janeiro (September, 2004). The disease appeared to have a fungal etiology since fungal stromata were closely associated to the advance of tissue necrosis. Photographs of symptoms were taken in the field and Botanical specimens as well as specimens of diseased foliage were collected for further study in the Mycology Lab at the Departamento de Fitopatologia (Universidade Federal de Viçosa). The botanical specimen was mounted and sent to the expert in the taxonomy of the Magnoliaceae (Dr. Stephen Smith, Smithsonian Institution) who identified it as Magnolia aff. candollei (Blume) H.Keng. (= M. liliifera).

Free hand sections of fungal structures on leaves as well as sections made with a freezing microtome (Criostat - Leica CM
1850) were prepared and mounted in water or lactophenol for observation under a light microscope (Olympus BX 50) fitted with camera. An ascomycete accompanied by two anamorphic stages was recognized forming stromata on the diseased leaves and readily identified with the keys provided in (13) as a member of the genus Botyosphaeria. A representative specimen was deposited in the local herbarium (Herbarium VIC 27786). As no record of a fungal disease was found for this host in Brazil a complete elucidation of the identity of the fungus involved was prepared and is presented below.

Botryosphaeria ribis Grossenbacher \& Duggar (teliomorph) and Fusicoccum ribis Slippers, Crous \& M.J. Wingf(anamorph) on Magnolia aff. candollei:

Disease: On living leaves, always starting apically as a necrosis at the leaf margins expands towards the midrib irregularly and occasionally advanced towards the base and leading to a complete blight of the leaf; adaxially, infection front is a diffuse zone of chlorotic tissue followed by a distinct band of dark brown necrotic tissue which is substituted later by an area of grayish brown tissue, where black stromata are visible arranged in concentric rows, as infection advances; abaxially the infection front is as seen adaxially but it is either

*Corresponding Author. Mailing address: Departamento de Fitopatologia, Universidade Federal de Viçosa, 36570-000. Viçosa, Minas Gerais, Brazil.

E-mail: rbarreto@ufv.br 
followed by an area of homogeneous pale brown necrosed tissue or additional irregular dark brown bands subdivide the areas of dead tissue, no stromata are normally visible abaxially (Figs. 1-2).

Fungus morphology: Internal mycelium, 4.5-10.0 $\mu \mathrm{m}$ diam, branched, septate, dark brown. Stromata erumpent adaxially, organized in concentric rows on necrotic tissues, sub-pulvinate, botryose, 0.4-0.8 $\mathrm{mm}$ diam, composed of dark brown pseudoparenchyma. Pseudothecia immersed, subsphaerical to pyriform, 180.0-285.0 x 150.0-290.0 $\mu \mathrm{m}$, walls 35.0-58.0 $\mu \mathrm{m}$ thick composed of brown textura angularis; dehiscence ostiolate, circular. Pseudoparaphysis filiform, 1.5-2.0 $\mu \mathrm{m}$ diam, 1-3 septate, hyaline. Asci bitunicate, clavate, 8-spored, 72.5-100.0 x 12.5-
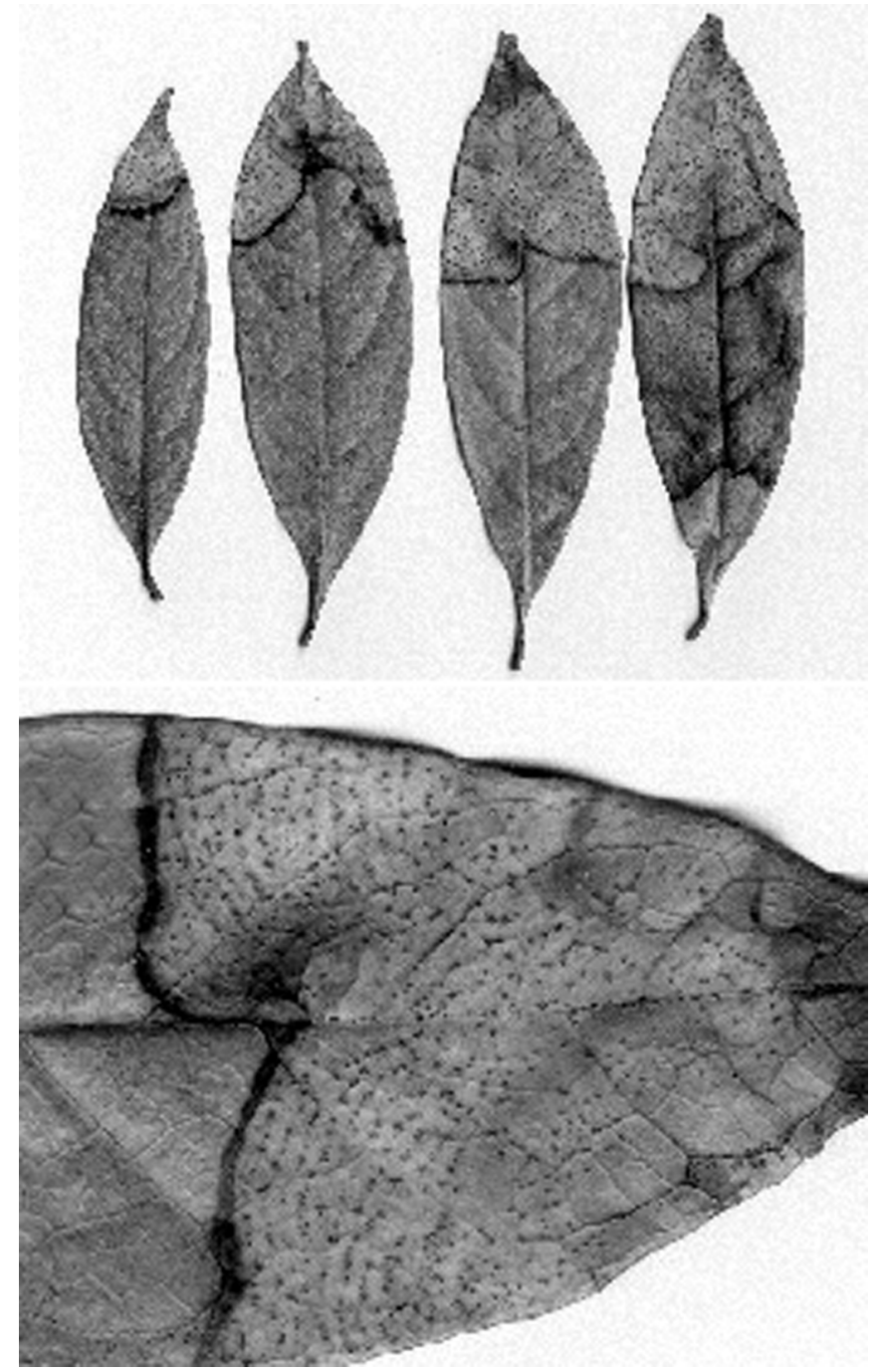

Figures1-2. Diseased foliage of Magnolia aff candollei showing progressive development of necrosis into almost complete leaf blight.
17.5 $\mu \mathrm{m}$. Ascospores ellipsoid, ovoid to fusiform, 19.5-24.5 x 9.5-12.0 $\mu \mathrm{m}$, aseptate, hyaline, smooth, with granular cytoplasm (Figs. 3-4).

Anamorph (F. ribis): Pycnidia globose to peroblate, immersed, isolate, 110.0-250.0 x 89.0-200.0 $\mu \mathrm{m}$, walls 14.0-25.0 $\mu \mathrm{m}$ thick, , smooth; dehiscence circular, $9.0 \times 12.0 \mu \mathrm{m}$ diam. Conidiogenous cells holoblastic, subcylindrical, 10.0-20.0 x 2.0$4.0 \mu \mathrm{m}$, hyaline; conidiogenous loci minute. Macroconidia fusoid, 19.0-25.0 $\mathrm{x}$ 4.0-6.0 $\mu \mathrm{m}$ aseptate, guttulate, hyaline, smooth. Microconidia alantoid, 1.0-4.0 x 1.0-2.0 $\mu \mathrm{m}$, hyaline, aseptate, smooth (Figs. 5-7).

Difficulties and controversy have surrounded the delimitation and identification of fungi in the genus Botryosphaeria and its anamorphs for very long. One such problem has been the separation of Botryosphaeria dothidea (Moug.) Ces. \& De Not. and $B$. ribis, regarded by different authors either as synonyms $(1,3,5,10)$ or distinct species $(8,12,16,20,21)$. Nevertheless, recent studies combining information from morphology and molecular markers have resulted in significant advances towards the elucidation of relationships within this ascomycete genus and

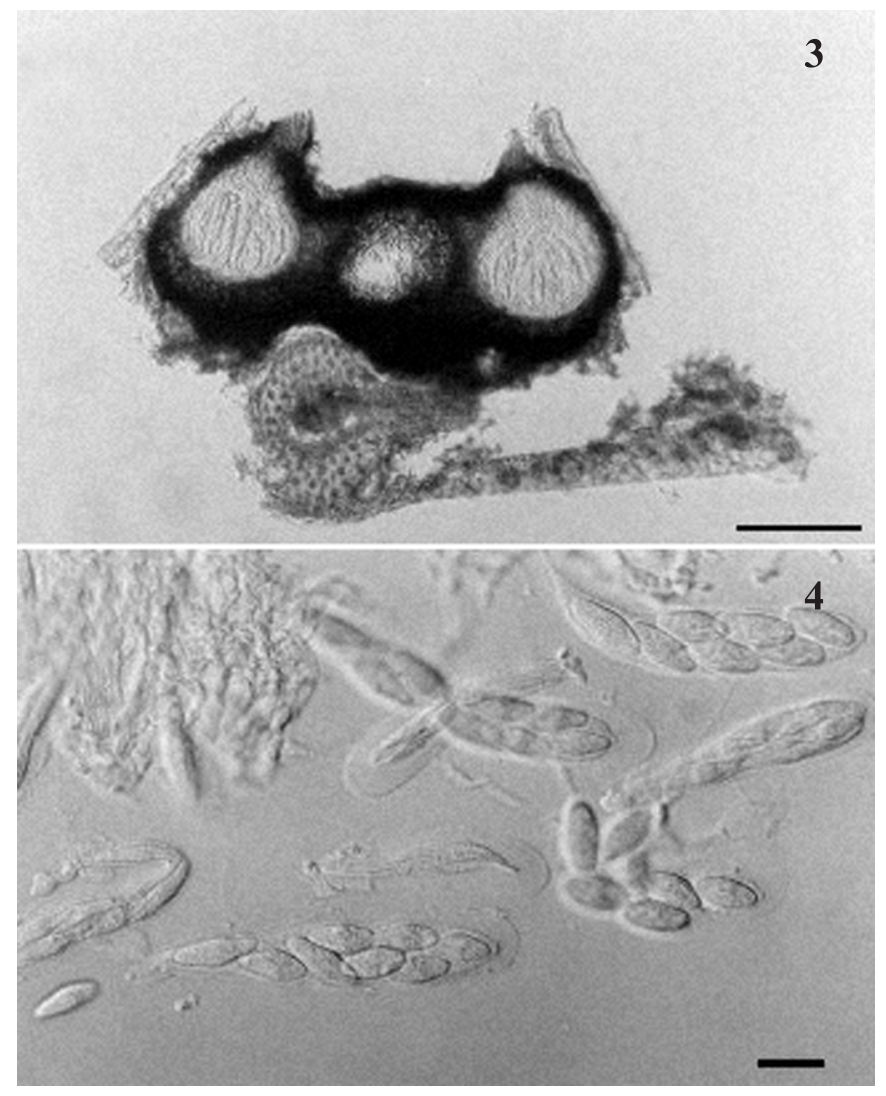

Figures 3-4. Botryosphaeria ribis: (DIC light micrographs). 3) Pseudothecia $(\mathrm{Bar}=140 \mu \mathrm{m}) ; 4)$ asci and ascospores $(\mathrm{Bar}=20$ $\mu \mathrm{m})$. 

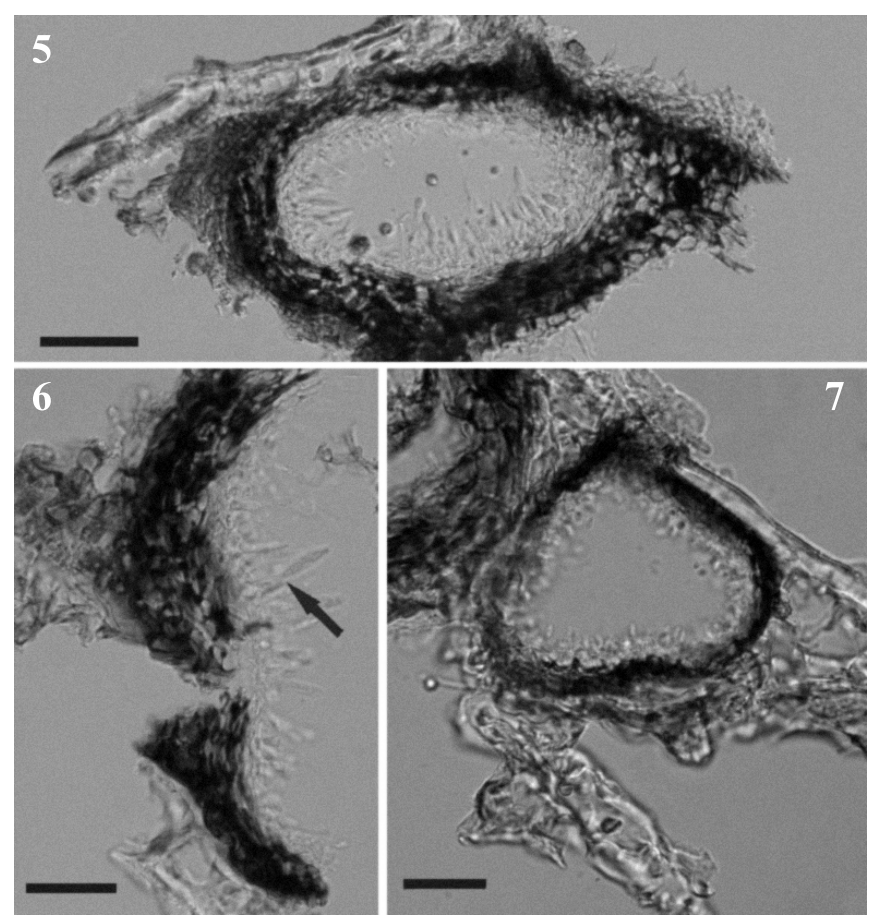

Figures 5-6. Fusicoccum ribis (DIC light micrographs). 5) Section of a pycnidium showing active production of conidia (Bar $=20 \mu \mathrm{m}) ; 6$ ) Detail of a pycnidium wall showing holoblastic conidiogenous cells (arrowed) $(\mathrm{Bar}=20 \mu \mathrm{m})$; 7) Conidioma producing microconidia $(\mathrm{Bar}=20 \mu \mathrm{m})$.

also including its anamorphs $(2,4,15)$. One such clarification was that $B$. dothidea and $B$. ribis are in fact distinct taxa (11,12,15-17,20,21). Besides molecular evidence for the separation of those two taxa, biometric data, particularly conidial length (conidia on average longer than $25 \mu \mathrm{m}$ in $B$. dothidea and shorter than $25 \mu \mathrm{m}$ in $\mathrm{B}$. ribis) are now recognized as useful for separating the two species $(7,9)$. The fungus on $M$. aff. candollei fits well within the species $B$. ribis. This is regarded as a polyphagous species attacking a wide range of hosts worldwide, including plants in the genus Magnolia $(12,19)$. In Brazil this fungus was only recorded attacking Eucalyptus spp. (6). In fact there is no record of any fungal disease of a Magnolia spp. In Brazil. Therefore, this is the first report of B. ribis and its anamorph F. ribis on Magnolia in Brazil and the first record of any fungal disease on a member of the genus Magnolia in Brazil $(6,18)$.

\section{ACKNOWLEDGEMENTS}

The authors thank the Coordenação de Aperfeiçoamento de Nível Superior (CAPES), Fundação de Amparo à Pesquisa do Estado de Minas Gerais (FAPEMIG) and Conselho do
Desenvolvimento Científico e Tecnológico (CNPq) for financial support and Dr. Stephen Smith (Department of Botany, Smithsonian Institution) for providing us with an identification for the plant.

\section{RESUMO}

\section{Primeiro relato de Botryosphaeria ribis associada com doença foliar em Magnolia aff. candollei no Brasil}

Neste trabalho são apresentadas observações feitas sobre a etiologia de uma doença foliar encontrada atacando alguns indivíduos da espécie Magnolia aff. candollei cultivados em um jardim particular na cidade do Rio de Janeiro. Esta doença se apresentava como manchas foliares que tendiam a coalescer levando à queima de áreas extensas das folhas atacadas. Um fungo estava claramente associado a estes sintomas e foi identificado como Botryosphaeria ribis. Seu anamorfo, Fusicoccum ribis, também estava presente, embora sendo menos comum que o teliomorfo. Este é o primeiro relato deste fungo neste hospedeiro no Brasil e o primeiro relato de uma doença fúngica em planta do gênero Magnolia no Brasil.

Palavras-chave: Magnoliaceae, planta ornamental, doença de planta, fitopatologia, taxonomia.

\section{REFERENCES}

1. Brown, E.A.; Britton, K.O. (1986). Botryosphaeria diseases of apple and peach in the Southeastern United States. Plant Dis., 70 (5), 480484 .

2. Denman, S.; Crous, P.W.; Taylor, J.E.; Kang, J.; Wingfield, M.J. (2000). An overview of the taxonomic history of Botryosphaeria and a re-evaluation of its anamorphs based on morphology and ITS rDNA phylogeny. Stud. Micology, 45, 129-140.

3. English, H.; Devay, J.E. (1975). Relationship of Botryosphaeria dothidea and Hendersonula toruloidea to a canker disease of almond. Phytopatology, 65(2), 114-122.

4. Jacobs, K.A.; Rehner, S.A. (1998). Comparison of cultural and morphological characters and ITS sequence in anamorphs of Botryosphaeria and related taxa. Mycologia, 90 (4), 601-610.

5. Maas, J.L.; Uecker, F.A. (1984). Botryosphaeria dothidea cane canker of thornless blackberry. Plant Dis., 68 (8), 720-726.

6. Mendes, M.A.S.; Silva, V.L.; Dianese, J.C.; Ferreira, M.A.S.V.; Santos, C.E.N.; Neto, E.G.; Urben, A.F.; Castro, C. (1998). Fungos em plantas no Brasil. Embrapa-Cernagen. Brasília, Distrito Federal.

7. Mohali, S.; Slippers, B.; Wingfield, M.J. (2007). Identification of Botryosphaeriaceae from Eucalyptus, Acacia and Pinus in Venezuela. Fungal Divers., 25, 103-125.

8. Morgan-Jones, G.; White, J.F.Jr. (1987). Notes on Coelomycetes. II Concerninig the Fusicoccum anamorph of Botryosphaeria ribis. Mycotaxon, 30, 117-125.

9. Pavlic, D.; Slippers, B.; Coutinho, T.A.; Wingfield, M.J. (2007). Botryosphaeriaceae occurring on native Syzygium cordatum in South Africa and their potential threat to Eucalyptus. Plant Pathol., 56 (4), 624-636. 
10. Pennycook, S.R.; Samuels, G.J. (1985). Botryosphaeria and Fusicoccum species associated with ripe fruit rot of Actinidia deliciosa (Kiwifruit) in New Zealand. Mycotaxon, 24, 445-458.

11. Punithalingam, E.; Holliday, P. (1973). CMI Descriptions of Pathogenic Fungi and Bacteria No. 395. Commonwealth Agricultural Bureaux, Kew, UK.

12. Rayachhetry, M.B.; Blakester, G.M.; Webb, R.S.; Kimbrough, J.W. (1995). Characteristics of the Fusicoccum anamorph of Botryosphaeria ribis, a potential biological control agent for Melaleuca quinquenervia in South Florida. Mycologia, 88 (2), 239-248.

13. Sivanesan, A. (1984). The bitunicate ascomycetes and their anamorphs. Lubrecht \& Cramer Ltd. Vaduz. Alemanha.

14. Souza, V.C.; Lorenzi. (2005). Botânica sistemática. Instituto Plantarum. Nova Odessa, São Paulo.

15. Slippers, B.; Crous, P.W.; Denman, S.; Coutinho, T.A.; Wingfield, B.D.; Wingfield, M.J. (2004). Combiend multiple gene genealogies and phenotypic characters differentiate several species previously identified as Botryosphaeria dothidea. Mycologia, 96 (1), 83-101.
16. Smith, D.R; Michaelides, T.J.; Stanouz, G.R. (2001). Differentiation of a Fusicoccum sp. causing panicle and shoot blight on California pistachio trees from Botryosphaeria dothidea. Plant Dis., 85 (12), $1235-1240$.

17. Smith, D.R; Stanosz, G.R. (2001). Molecular and morphological differentiation of Botryosphaeria dothidea (anamorph Fusicoccum aesculi) from some other fungi with Fusicoccum anamorphs. Mycologia, 93 (3), 505-515.

18. U.S. Department of Agriculture (2007). Fungal Databases, Systematic Botany \& Mycology Laboratory, ARS, USDA. Available at: http:// nt.ars-grin.gov/fungaldatabases/index.cfm. Accessed 11 September 2007.

19. von Arx, J.A. (1987). Plant pathogenic fungi. Cramer, J., Stuttgart, Berlim.

20. Zhou, S.G. (2001). Primers for amplification of mt SSU rDNA, and a phylogenetic study of Botryosphaeria and associated anamorphic fungi. Mycol. Res., 105 (9), 1033 - 1044.

21. Zhou, S.; Stanoxz, G.R.; (2001). Relationship among Botryosphaeria species and associated anamorphic fungi inferred from the analyses of ITS and 5.8S rDNA sequences. Mycologia, 95 (3), 516-527. 